\title{
Effect Local Direction on Balinese Traditional Settlement Layout, Case Study: Pengotan Traditional Village in Bali, Indonesia
}

\author{
I Kadek Merta Wijaya \\ Department of Architecture, Universitas Warmadewa, Bali, Indonesia \\ Received October 9, 2020; Revised November 30, 2020; Accepted December 13, 2020
}

\section{Cite This Paper in the following Citation Styles}

(a): [1] I Kadek Merta Wijaya, "Effect Local Direction on Balinese Traditional Settlement Layout, Case Study: Pengotan Traditional Village in Bali, Indonesia," Civil Engineering and Architecture, Vol. 8, No. 6, pp. 1395 - 1407, 2020. DOI: 10.13189/cea.2020.080622.

(b): I Kadek Merta Wijaya (2020). Effect Local Direction on Balinese Traditional Settlement Layout, Case Study: Pengotan Traditional Village in Bali, Indonesia. Civil Engineering and Architecture, 8(6), 1395 - 1407. DOI: 10.13189/cea.2020.080622.

Copyright $\mathrm{C} 2020$ by authors, all rights reserved. Authors agree that this article remains permanently open access under the terms of the Creative Commons Attribution License 4.0 International License

\begin{abstract}
The pattern of Pengotan Village is extended from the kaja (sacred) to the kelod (profane), which consists of three zones, namely the Utama (zone of sacred) as the space intended for shrines (temple), Madya (transition/between space) as the space for residential housing units, and the Nista zone (zone of profane) intended for the graveyard (setra). This pattern is repeated in clusters of residential housing units. The aim of this study is spatial analysis of luan (sacred) and teben (profane) orientations in Indigenous Village Pengotan through an approach: (1) history of the Traditional Village Pengotan, (2) conception of the mountain as a sacred direction, (3) conception luan (holy) and teben (profane) on settlements in the mountainous area, (4) general concepts of religious and secular space and (5) conception of signifier and signified spaces in architecture. The method used is naturalistic interpretive in studying the area in a conceptual (intangible) and concreate (tangible) context through empirical studies on sensual (observation), native's viewpoint, logic viewpoint (researcher's perspective), and intangible aspects. The results of this study are (1) spatial patterns based on luan (sacred) and teben (profane) conception; (2) the signifier and signified system in the space of on luan (holy) and teben (profane) orientation and (3) the relationship between Mount Batur and Mount Abang as luan (sacred) orientation in the Pengotan Village.
\end{abstract}

Keywords luan (sacred) and teben (profane) Orientation, Tuluk Biyu Temple, Mount Abang, Signifier and Signified System, Spatial Patterns

\section{Introduction}

The luan (sacred) concept in the spatial of sacred and profane orientation is called Kaja (north) and Kangin (east). Kaja is identified with the mountain's direction, and Kangin is the direction of the rising sun. In the Hindu-Balinese orientation, the hill is a symbol of the dwelling of God's and deceased ancestors [1] [2] [3] [4]. To honor the ancestors and the gods who are believed to provide safety and well-being, the layout of highland settlements is oriented towards the mountain (Kaja / high place). The profane concept describes the opposite of Kaja (the direction of a hill of sacred value), and Kangin (sunrise direction of holy value) is the direction of Kelod (movement of the sea of offensive matter), which is identified with a commonplace or land and Kauh (direction of the sunset of profane value) direction in the form of the sun sinking. The concept of luan (sacred) and teben (profane) in Bali's residential spatial planning is generally in mountainous settlements called Bali Aga settlements. Bali Aga is a term used to refer to ancient Balinese settlements with the afterward settlements; Bali Aga is in a mountainous or highland area [5] [6] [7] [8].

The concept of luan (sacred) and teben (profane) 
correlates with religious and secular; the orientation of luan is characterized by zoning the holy and unholy symbolized by zoning the teben area. Sacred space is generally used as worship spaces in connecting humans' spiritual nature with God through ritual symbols. Profane space correlates with zones for physical activity or does not connect with God [5] [9] [10] [11]. The layout of Pengotan Village has a linear pattern which is divided into three zones, namely the Utama (Sacred Place / Desa Temple, Puseh Temple, Bale Agung, and Prajapati Temple), the Madya zone (residential area), and the Nista / low zone (Setra / cemetery). The zoning is based on the orientation of luan (sacred) and teben (profane), which is also the direction of religious orientation (Tuluk Biyu Temple / Kaja) and teben as the direction of profane orientation (low place / kelod). Desa Temple, Puseh Temple, Bale Agung Temple, and Pajapati Temple are symbols of worship of God or the mountain's character as a residence place for the gods. In this context, Tuluk Biyu Temple is the spirit of Pengotan Village residents in a high area. The luan zone has a sacred meaning, so there are local rules for entering the temple area. The concept of a high land such as a mountain is a symbol of where the sky meets (purusa / male aspect) and earth (predana / female part). The meeting of heaven and earth creates a balance in the universe's prosperity [5] [12].

The concept orientation of luan (sacred) is also often illustrated in the "home garden" unit. The residential units of the Pengotan villagers line up in a linear pattern, with the village main road as the axis of the linear spatial structure. One cluster of residential units consists of several family leaders related to each other (family). One family unit consists of three zones, namely tegak sanggah (holy place), tegak umah (meten/below building and bale building), and tegak teba (empty land or multifunctional area). The utama (sacred) orientation of the yard of one family unit is towards luan (kaja / Tuluk Biyu Temple), and the nista orientation (profane) is towards teben (house yard). The home garden unit's luan orientation marking system is sacred and worship orientation towards kaja (Tuluk Biyu Temple). Another marker is the occupant's sleeping position orientation with his head towards the kaja (Tuluk Biyu Temple). The teben (sacred) orientation is the opposite direction in the form of teba (profane) and lebuh (profane). Lebuh (profane) is the lowest direction in the concept of luan (sacred) and teben (profane). This direction is used as a ritual activity for the cosmic realm in bhuta (the universe's physical element). In addition to this, space is used as a ritual for the cosmic realm is natah (plaza). Natah (plaza) is the orientation of building masses (meten buildings / main building and bale buildings periphery) and is used for religious ritual activities and social activities. As a ritual space for the cosmic realm, natah (plaza) has a meaning as a space of balance between the sekala (tangible) and the Niskala (intagible). Sekala (tangible) in the context of luan (sacred) orientation and teben (profane) is (earth / predana / female symbol) as a physical and Niskala (intagible) is the soul as the luan (sacred) orientation (sky / purusa / male symbol) [13] [14].

The concept of luan (sacred) in the spatial layout of Pengotan Village housing is not only towards Kaja (Tuluk Biyu Temple) but also the Kangin (Mount Abang). The direction of Kangin (Mount Abang) is marked by the orientation position of pelinggih (worship element) for the ancestors of the Pengotan Village inhabitants, which is on the slopes of Mount Abang (Kangin). Before immigrating to another place, residents of Pengotan Village settled on the slopes of Mount Abang. Therefore, in the form of respect for the origin of the area of birth, it is manifested in the form of a cult that faces Kangin (luan). The same direction also occurs in the head of the corpse towards Kangin (Mount Abang) as a form of a life cycle returning to the origin of the place of birth. This concept is following the statement that the sun rises oriented towards the east (Kangin) so that it has a high value or sacred and is used as a parhayangan area (family sanctuary) [15] [16].

The purpose of this study is a study of luan (sacred) and teben (profane) orientation spatial planning through an analysis of behavior systems and zoning systems, a network of signifier and signified of elements in the direction of luan (sacred) and teben (profane), and a study of the history of the origin of the inhabitants of Pengotan Village. The course uses qualitative interpretive naturalistic methods by analyzing sensual (natural observation), emic (native's viewpoint), ethical, logical, and intangible aspects. The results of this study are: (1) spatial patterns based on luan (sacred) and teben (profane) conception; (2) a signifier and signified system in the direction of luan (religious) and teben (earthly) and (3) the relationship between the Tuluk Biyu Temple and Gunung Abang as a luan (sacred) orientation in the Pengotan Traditional Village.

\section{Materials and Methods}

This research is located in the Pengotan Traditional Village as one of the mountain villages in the Bangli area. The uniqueness of the village is to have a core zone (traditional housing) and periphery zone (garden house), as well as a linear village pattern with the concept of orientation that is still ancient, namely luan (sacred) and teben (profane). The method used in reviewing the concept of luan (holy) and teben (profane) orientation is interpretive naturalistic. In interpreting the orientation concept of luan (sacred) and teben (profane) in Pengotan Village, researchers used a method of data analysis with sensual empirical (natural observation), practical logic, empirical emic (native's viewpoint), empirical ethics, and transcendental [17]. The study focuses on behavioral 
systems and space zoning and marking schemes, direction signifier spaces at the luan position (sacred), and teben (profane). The research instrument used was a variable researcher in the form of a signifier. It signified luan (religious) and teben (secular).

In contrast, the independent variables were the community's values and behavior in using space, the history of Pengotan Village formation, and the relationship between Pengotan Village residents and their natural environment. In producing transcendental findings in natural settings, data collection is focused on unstructured interviews with traditional village leaders and local communities by not intervening in the information obtained - a sensual empirical study through observation of empirical data using photo and sketch media in a research logbook. The information obtained was analyzed through a dialogue approach to findings with highland area architectural designation concepts to explain the results and conduct an induction or synthesis process to produce transcendental.

\section{Research Result}

\subsection{Description of Traditional Pengotan}

Pengotan Village is one of Bali's old villages characterized by the craftsmanship order (saints occupy governance) called peduluan. Unlike the village government system, it consists of the village head, secretary, treasurer, and staff assistants. Pengotan village is a new village formation in ancient times, originated from Karangasem Regency, on the Abang Mountain and Tuluk Biyu Temple. Therefore, kawitan (the place of origin/ancestor) of the Pengotan Indigenous Village community originated from a village on the slopes of Mount Abang, precisely located in the east (Kangin) the Village of Indigenous Pengotan now. The history of the Pengotan starts from the Gegebug Expedition (control of the territory) of Panji Sakti King in Singaraja. Information that spread was that King Panji Sakti would pass the slopes of Mount Abang. Village Elders held deliberations on this matter, and it was decided to move to the south to find a safe place from the attack of King Panji Sakti. Finally, in the southern part of the Bangli region, and was well received by the ruling king of Bangli because the community had well-honed artistic creativity while living in the forest on the slopes of Mount Abang. The community's first work in Bangli was Dalem Purwa Temple as the forerunner of the ancestors of Pengotan Village. The next development is Desa Temple, Puseh Temple, and Dalem Temple as manifestations of the Tri Murti concept (the concept of Hinduism's three main deities). Then there was social friction between immigrant villages and local villages. Bangli authorities liked immigrants because of their creativity, so immigrant communities were saved by moving them to a safe place (now called Pengotan Village). The movement of the city brings its inscriptions and culture in adaptation to the surrounding environment. When determining the starting point of Pengotan Village, which was initially a wilderness, lateng plants were found (the Latin term called Dendrocnide macrolides) which had been eaten by tree caterpillars (called subatah) and dirt from eating plants such as oot (bran) then the area this is called Pengotan.

Pengotan Village has a macro zoning system divided into two: main village (adat) and periphery village (secular). Its culture and customs still maintain this village to date. The main village has a linear pattern with clusters with a linear configuration and is inhabited by elders of each family who have been ritually purified. People who work as farmers prefer to live in a "garden house" and return to the main house if there are traditional ceremonies. The people who live on agricultural land are divided into 8 (eight) banjar (the smallest unit of the ancestral village) around the core village, namely Banjar Tiying Desa, Banjar Delod Desa, Banjar Dajan Desa, Banjar Yoh, Banjar Besenga, Banjar Penyebeh, Banjar Padpadan, and Banjar Sunting. (see Figure 1). 


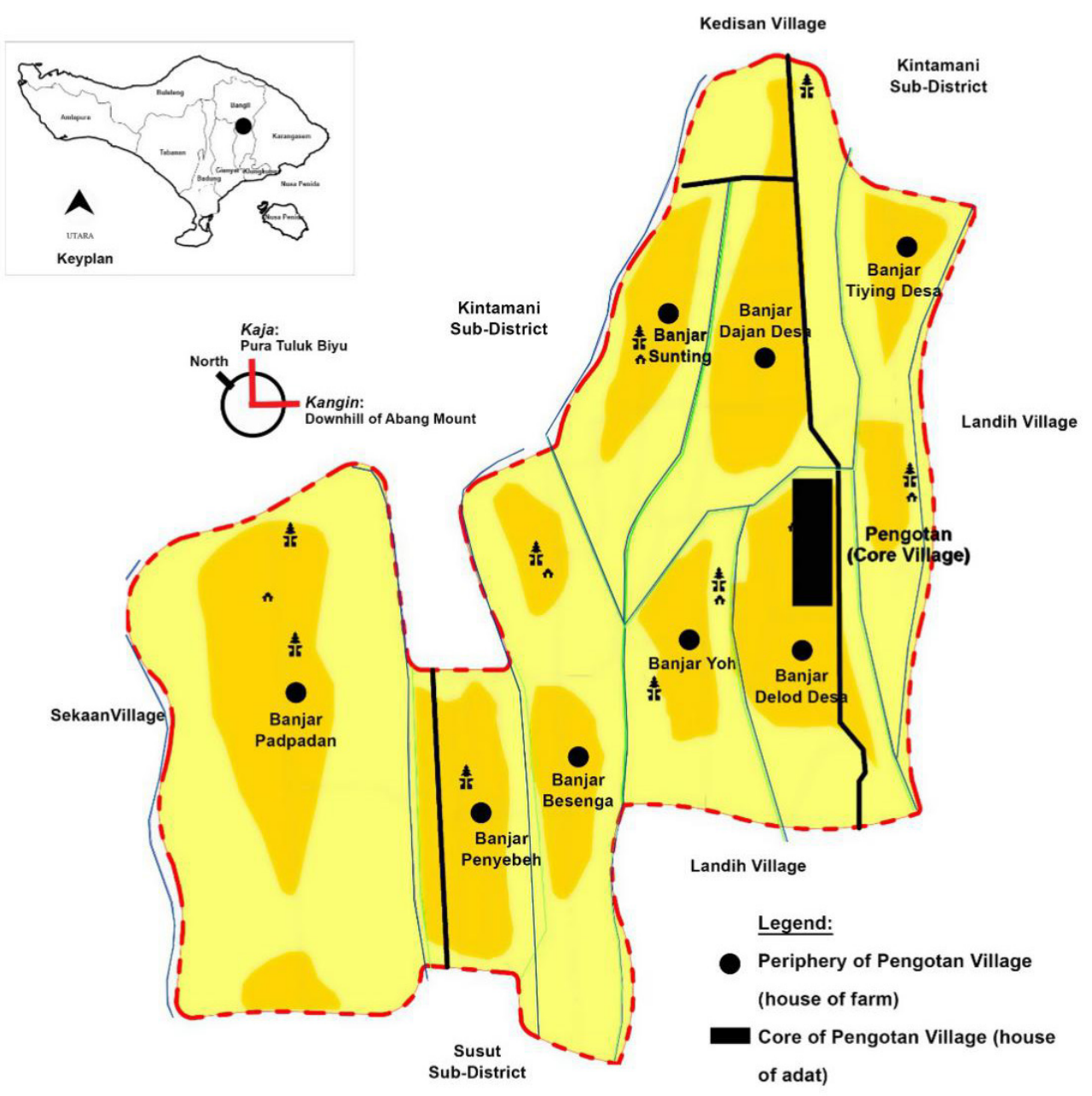

Figure 1. Core village (adat) and periphery village (secular) of Pengotan Village

\subsection{Luan (Sacred) and Teben (Profane) Orientation System at the Village Unit}

The spatial pattern of Pengotan Village is divided into three, namely Utama (sacred zone), Madya (housing / secular area), and Nista (cemetery/offensive zone). Determination of the main orientation direction is determined based on principle (the residence of the gods/ancestors) and the direction of teben (low place direction/opposition from luan direction). The village's orientation in Pengotan is identified as the direction of kaja (the order of Tuluk Biyu Temple) as a sacred direction. The concept of luan (holy) and teben (profane) in the linear pattern in Pengotan Village is seen in the configuration of building masses that function as religious rituals, housing functions, and agricultural functions, and public spaces. The signified system and directions from the luan (sacred) and teben (profane) orientation in Pengotan Village are explained as follows:

The luan (heavenly) is marked by the configuration of the holy places' cluster buildings, namely Bale Agung Temple, Puseh Temple, Desa Temple, and Prajapati Temple. (see Figure 2). The temples are a symbol of God's worship in a higher order of functions except for
Prajapati. Unlike other villages in Bali, the position of the Prajapati Temple is a symbol of death, which is generally placed in the cemetery zone (setra) in teben (profane) village, in the Pengotan Village, the holy place is in the luan (sacred) zone. The Parajapati Temple in Pengotan Village is located in the other villages, precisely in the village of Desa Temple and Puseh Temple. This means that (1) Pengotan Village is an ancient village that immigrated to the Bangli area which did not recognize the concept of burning dead bodies and ceremonies in raising the deceased's status to a higher place. People who have died without carrying out the process of the death ceremony are still seen as dead ancestors and are at the upper level, and (2) the layout of Pengotan Village shows that the position of the Prajapati Temple is in the middle of the cemetery zone even though it is not in one area. The masses of buildings in the luan zone have an orientation towards Kaja (main direction) where the gods and ancestors have died. The Kaja exposure is the Tuluk Biyu Temple, which is in the east of Mount Batur. The concept of luan (sacred) is related to the idea of ancestors-related [18]. The ancestors are the gods who have given welfare to the community in the form of the existence of forests 
and the supply of water resources used by Pengotan Village people. Other zones are intended for worship facilities (temples), which have sacred values in the layout of Pengotan Village compared to different zones. Following Eliade's statement, the holy space in Pengotan Village states that the sacred space, also called "temple" is a space to get a chaotic orientation of profane world homogeneity, find the world and feel the real nature [19] [20].

The teben (profane) spatial is an opposition from the luan (sacred) space. In the village Pengotan, the signifier of the teben (secular) area is a space intended for pitra yadnya ceremonies (ceremonies intended for deceased humans) and bhuta yadnya (rituals designed for the cosmic realm). The people of Pengotan Village who have died will be buried and burned in Setra (cemetery), which is in the direction of teben (offensive zone) in the pattern of Pengotan Village, precisely the lower end (kauh / profane) of the main village. (see Figure 2). Pengotan village has a burial site (setra) which is divided into four parts, namely (1) kaja (main direction / Tuluk Biyu Temple) zone intended for burial for deceased saints, (2) kangin (Abang Mount) zone for the funeral of female bodies, (3) kelod (kangin opposition) zone for the burial of male bodies and (4) zones for the tomb of the bodies of children. In the zoning arrangement for a corpse funeral, the luan concept is considered a funeral for a saint. The saints in Pengotan Village are elders who have been ordained in religious customs and are deemed to have a higher position than the community. In the ceremony at Bale Agung Temple, there is a building in the form of an elongated shape called Bale Agung. The building is intended for saints in Pengotan Village. The main village's end zone is precisely in the other part of the blind area; there is a road cross formed by the vertical (primary) and horizontal axis. At the point of the room is a place for performing bhuta yadnya (ceremonies intended for the cosmic realm) ceremonies at the expense of (slaughtering) a cow. This pitra yadnya ceremony aims at rituals intended for Bhuta Kala (cosmic realm) to create a natural balance. Anythings of ritual activities carried out by Hindus in Bali to glorify and maintain cosmic balance are based on the emergence of human consciousness centered on nature (cosmos) [21] [22] [16]. This zone is also intended for nebusin ritual activities or ritual ceremonies to take back the surviving human spirits held by local people in the trust of the bhuta (spirits). (see Figure 2). So it can be concluded that the teben (profane) space is a space for secular activities such as the burial of bodies, rituals related to the cosmic realm.

The madya space (middle) in the Pengotan Village is marked by a zone of the locals' home garden units. The residential yard units are lined up and have a linear pattern, with the village's main road as its central axis. Each yard unit is connected to the village main road by road to each yard unit. The orientation of these yard units towards luan
(Tuluk Biyu Temple) is marked by a holy place (objection) for each family and the direction of the teben (profane) in the form of an entrance to the yard unit. That means that the concept of luan (sacred) and teben (profane) in village units has the same residential units pattern. The activities carried out in this zone tend to be related to humans and society. As a place to live and establish local people's social life and ritual activities related to humans (manusa yadnya). (see Figure 2). Looking at the relationship between the concept of luan (sacred) and teben (profane) in the settlement unit of Pengotan Village, that luan (religious) is identified with something sacred (soul) and teben is profane (body).

Pengotan Village residents guard the two poles through ritual activities and attitudes towards space in various daily activities. The Hindu-Balinese community believes that harmonizing the two areas affects the continuity of the lives of the people who occupy residential space/middle space / madya space (pawongan/ zones for residential homes). The statement of two opposing poles that complement each other, namely in Kusdiwanggo's research on Sakuren, complementary relations are not mutually dominating or controlling. In other terms, there is no dialectic and tension; there is harmony [23] [24].

In the context of luan (sacred) and teben (profane) dichotomy, both poles or orientations must be maintained in creating a point of balance, namely the space between or transitions of the opposite poles. Then the term triadic is known in spatial planning in Bali; they are utama (luan / sacred), madya (middle), and nista (teben / profane). The middle space (madya) is a balance point between the utama (sacred) space and the nista (profane) space called natah (plaza/space). The yard's core space is used as a ritual space to balance the Sakala space and Niskala called Natah [13] [25] [26] [27] . Natah or midpoint is a space in Pengotan Village in pempatan agung or area in the village center. Pempatan Agung is used as a space to hold the Pecaruan Agung (ceremony for spirit) ritual ceremony to balance the macrocosm and the microcosm. The madya space is a balance between the luan (sacred) and teben (profane) pole.

The orientation systems of luan (sacred) and teben (profane) are also illustrated in the concept of houses in Pengotan Village, namely "traditional houses" and "garden houses." Pengotan Village, divided into 8 (eight) traditional banjar (the smallest unit of the village) is a zone intended for secular activities, namely farming or gardening activities. The livelihood of the residents of Pengotan Village is mainly to cultivate agricultural land, so they must establish lodgings that develop into "garden houses." Whereas in traditional houses is a space for religious ritual and regular ritual activities. Daily activities take place in the "garden house" while those who manage traditional houses are elders who have been traditionally appointed to live in conventional homes. In conjunction with the luan (sacred) and teben (profane) orientation 
system, the traditional house is a usually arranged space and is intended for religious and ritual activities. In contrast, the "garden house" is used for secular activities (livelihood space). Therefore, the concept of local wisdom regarding initial spatial planning in Pengotan Village has been maintained through luan (conceptual/sacred) conception as space and orientation that needs to be preserved as the core of the room or area Pengotan Village.
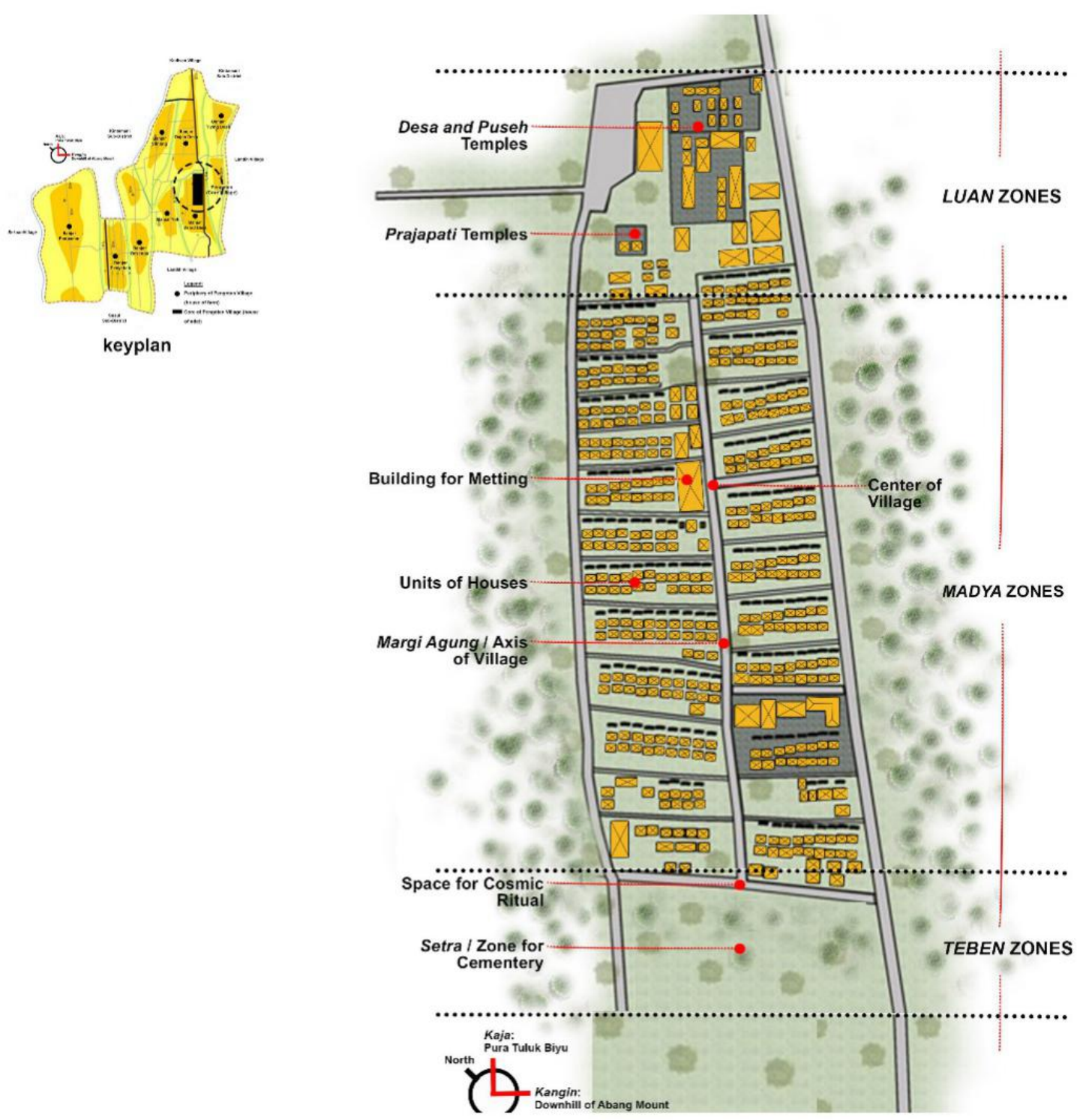

Figure 2. Luan, Madya, Teben Zones of Pengotan Village 


\subsection{Luan (Sacred) and Teben (Profane) Orientation System in the House Yard Units}

The home garden unit's layout is a configuration of cluster housing yards lined up in a linear pattern and bound by a central axis called Rurung Desa (the village's main road). One home garden unit consists of 8 to 10 family heads who have blood relations. Home units in the yard unit with blood relations can be seen from the marker in the form of a sacred place (sanggah / temple to ancestors), which protects several housing units and has one entrance to the sanggah area and the yard of the house One branch of the home garden is divided into three zones; they are tegak sanggah zone (sanctuary zone), tegak umah zone (home zone), and tegak teba zone (flexible space / low-value space). The outermost part of the tegak teba (flexible space / low-value space) is lebuh (the outer part of the house) or rurung (road). Tegak sanggah (sanctuary zone) is luan (sacred) of the house yard, tegak umah (home zone) as the middle zone (middle) and tegak teba (flexible space / low-value space) and lebuh (the outermost part of the house) as the teben (profane) zone of the home garden unit. According to Wijaya stated that the transformation of space starts from luan (sanggah) then the home garden unit, and if there is an increase in building mass, the zone used is the red zone. The addition is like a bathroom. Thus, the movement of the site starts from luan (sacred) then moves downstream (teban) [28] .

The addition of a new family head affects a housing unit's expansion to stay away from the axis of the village's main road to the limit determined by the village. The addition of houses does not affect the proliferation of sanggah (holy place) if the new family head has a family relationship with the family who has settled in that place. As the village's central axis, the main road has the initial space connects the luan and teben areas. Some axes bind two building masses in the house yard unit, namely meten buildings (main building) and bale buildings (building for traditional activities). The middle space or natah (plaza) is an outer space that is used as a ritual space for the cosmic nature (bhuta), the space for bathing the body before being sent to the cemetery (setra), and the social space of the community (gathering), when there is a formal event in the house. Natah is a space, and the intermediate area is a symbol of balance between luan (sacred) and teben (profane). The balance concept meets the two elements giving birth to the motion of life, purifying the universe from harmful components that threaten humanity's energy and experience in the universe (balance) [29] [30].

As a space for balance, natah (plaza) in Pengotan Village functions as a space for performing the pecaruan ceremony (cosmic natural ritual), bathing the corpse, which means freeing and cleansing worldly elements that are still attached to the body of the deceased person which is done at a neutral point (empty / natah ) and social space (community gathering place). The luan (sacred) and teben (profane) orientation system in the house yard unit is shown in Figure 3.

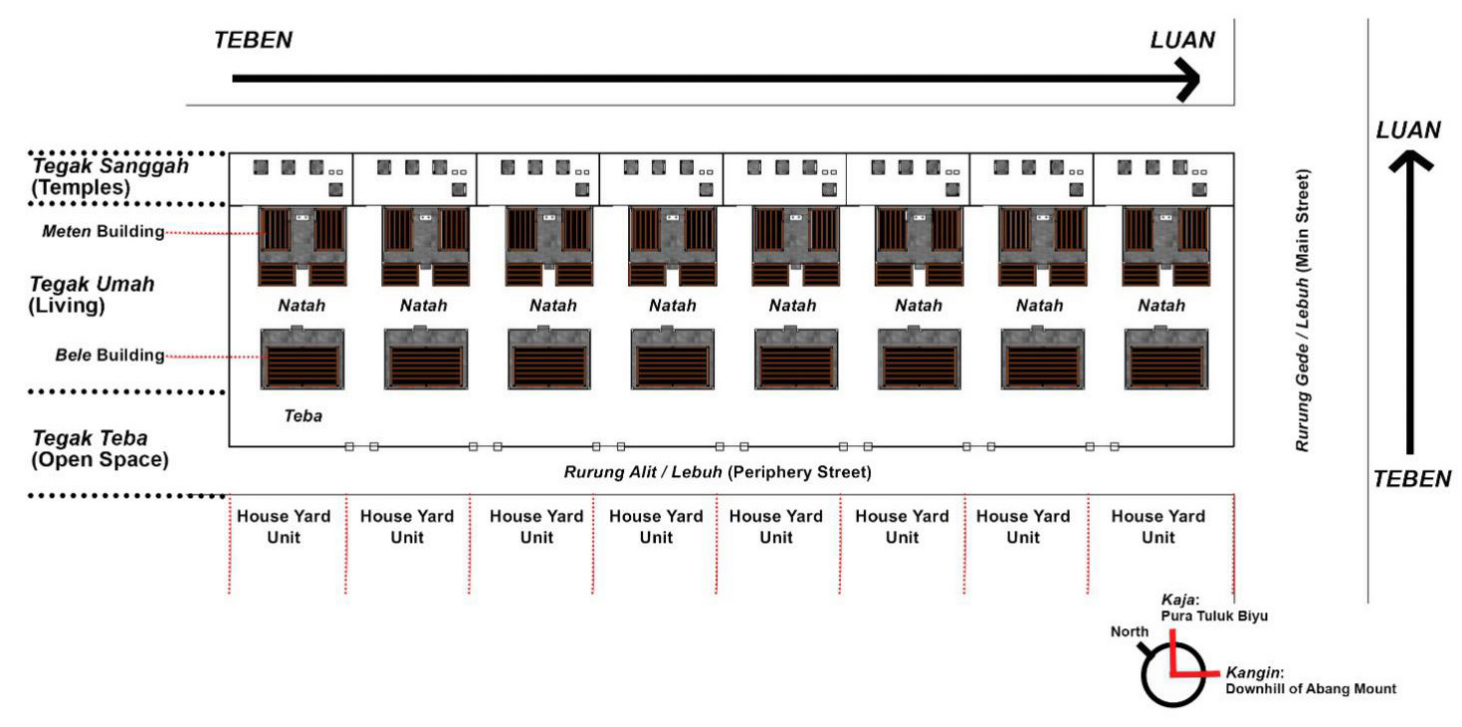

Figure 3. Luan and Teben Orientation System in the House Yard Units 

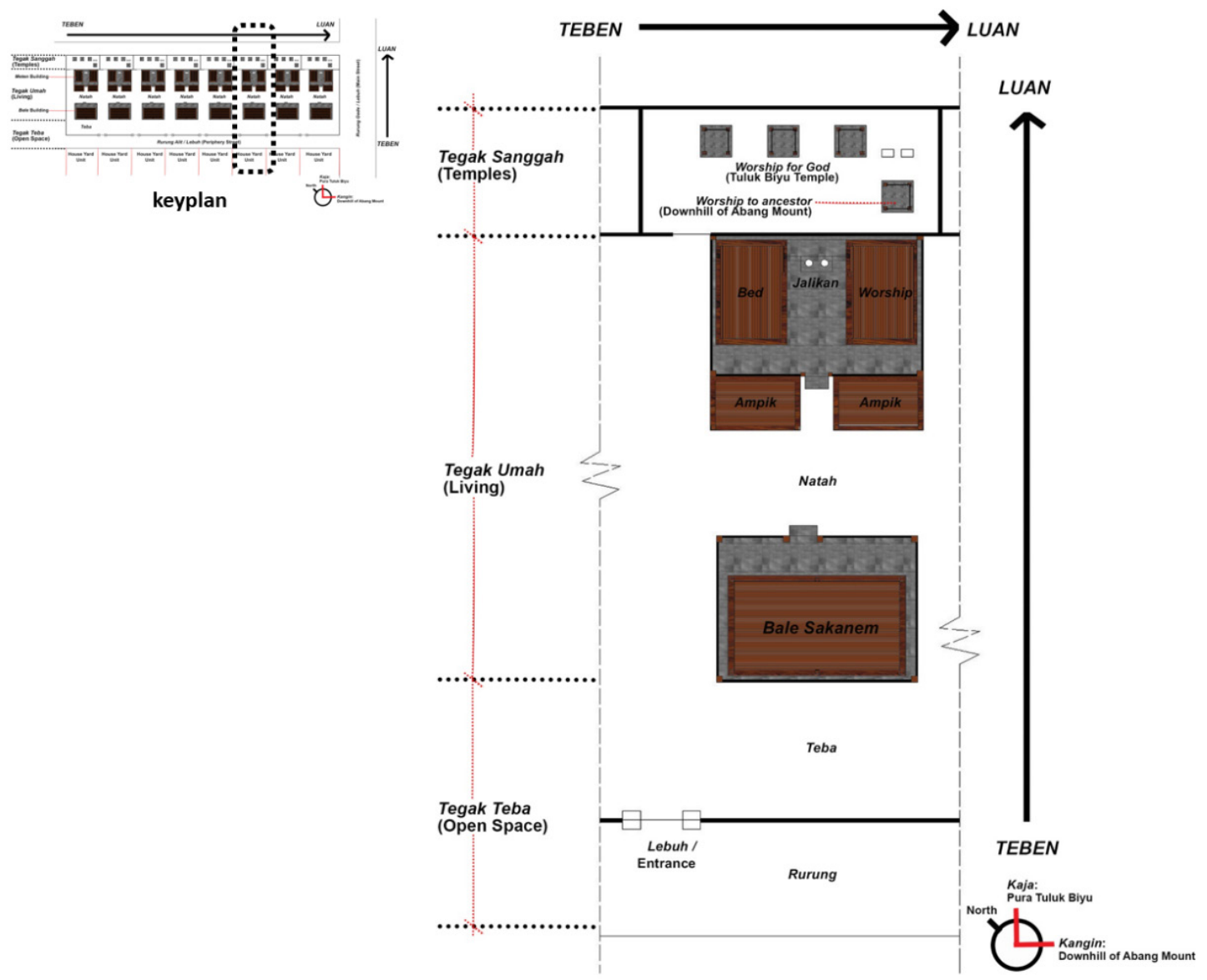

Figure 4. Luan and Teben Orientation System in Sanggah, Meten Building, and Bale Building

\subsection{Luan (Sacred) and Teben (Profane) Orientation System in Sanggah (Temple to Ancestors), Meten Building (Main Building), and Bale Building (Building for Tradition Activities)}

The pattern of garden unit management in one family consists of three zones, namely tegak sanggah (luan/sanctuary zone), tegak umah (madya / home zone), and tegak tebe (teben / flexible space / low-value space). Tegak sanggah (sanctuary zone) consists of worship buildings (pelinggih), which have an orientation towards kaja (sacred) and kangin (profane). The Kaja (primary path) direction as a qibla in the worship of gods is located in Tuluk Biyu Temple. The rule of kangin as a qibla towards Mount Abang as the origin (kawitan) of the Pengotan Village residents. In this context, worship of the deity in Tuluk Biyu Temple has provided welfare to Pengotan Village residents through a system of irrigation and rain for agriculture and worship of ancestors (kawitan) who once lived on the slopes of Mount Abang. (see Figure 4).

Tegak umah (home zone) consists of meten buildings (main building), bale buildings (building for traditional activities), and spaces between natah (empty spaces). The orientation of the meten building (main building) towards Kaja (luan / sacred/main direction) has two areas, namely the inner room and the terrace (ampik). The space in the meten building (main building) is divided into three zones, namely dipan (bale/bed) as a bed, dipan (bale/bed) as a ritual place, and the middle zone between the two Bale (foundation), which consists of a cooking stove (penyalikan) and a furniture cabinet. The orientation of the three spaces towards Kaja (luan / sacred), the sleeping position of the occupants of the house with heads towards luan (Kaja / religious), the orientation of worship rituals and offerings are oriented towards Kaja (luan / sacred), and the mouth position of the cooking stove (penyalikan) facing the kelod (profane) which means the part of the person cook oriented towards the Kaja (luan / sacred). The means that the interior layout orientation of the meten building (main building) is oriented towards luan (kaja / sacred), which is the direction of the place where Bhatara Shiva Giri Natha (God) lives, which can provide welfare in the form of protection and fertility in the area of Pengotan Village. Ampik (terrace) space is the front porch of the meten building (main building), which functions as a social space for family members. (see Figure 5). 


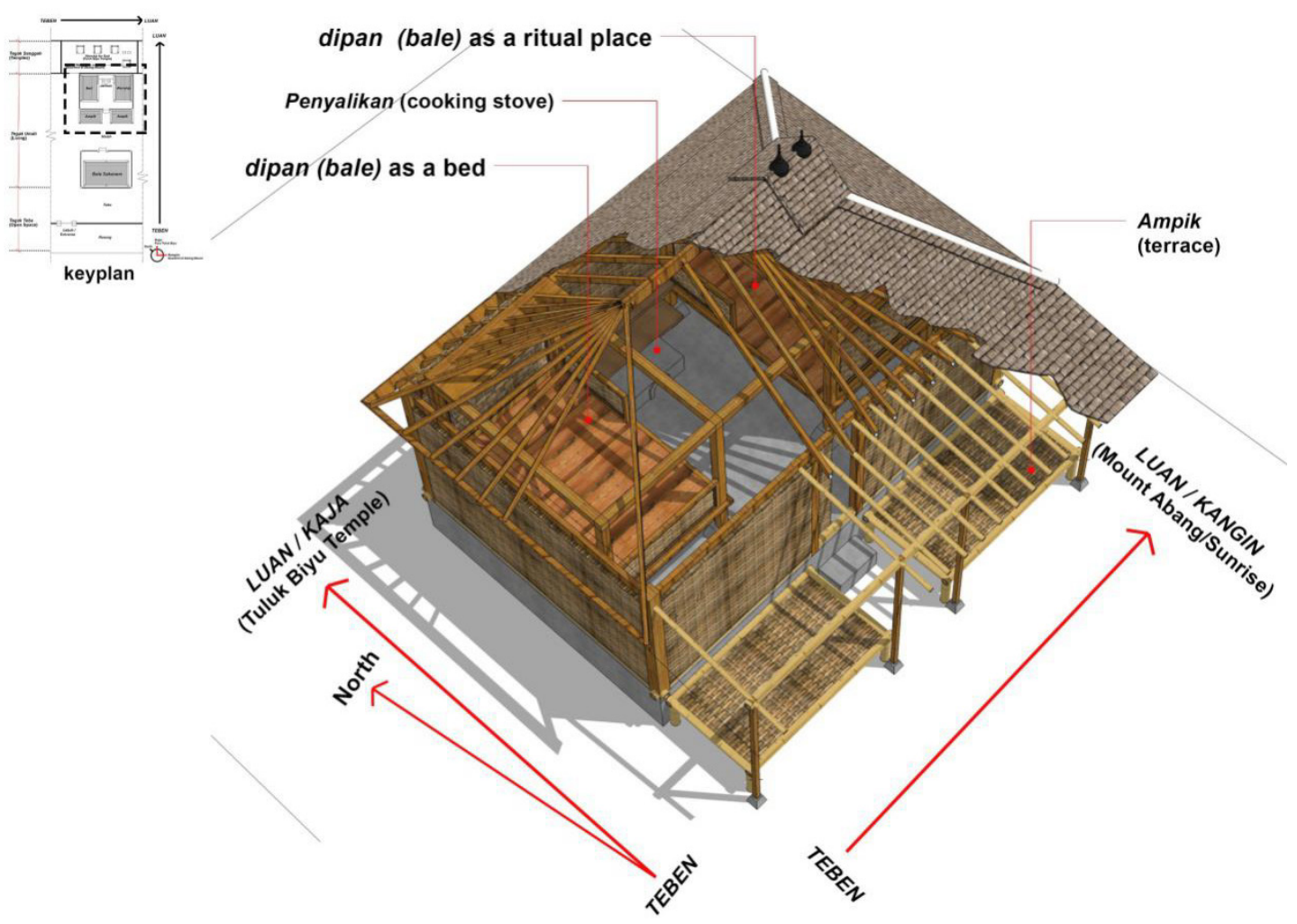

Figure 5. Luan and Teben Orientation of Meten Building

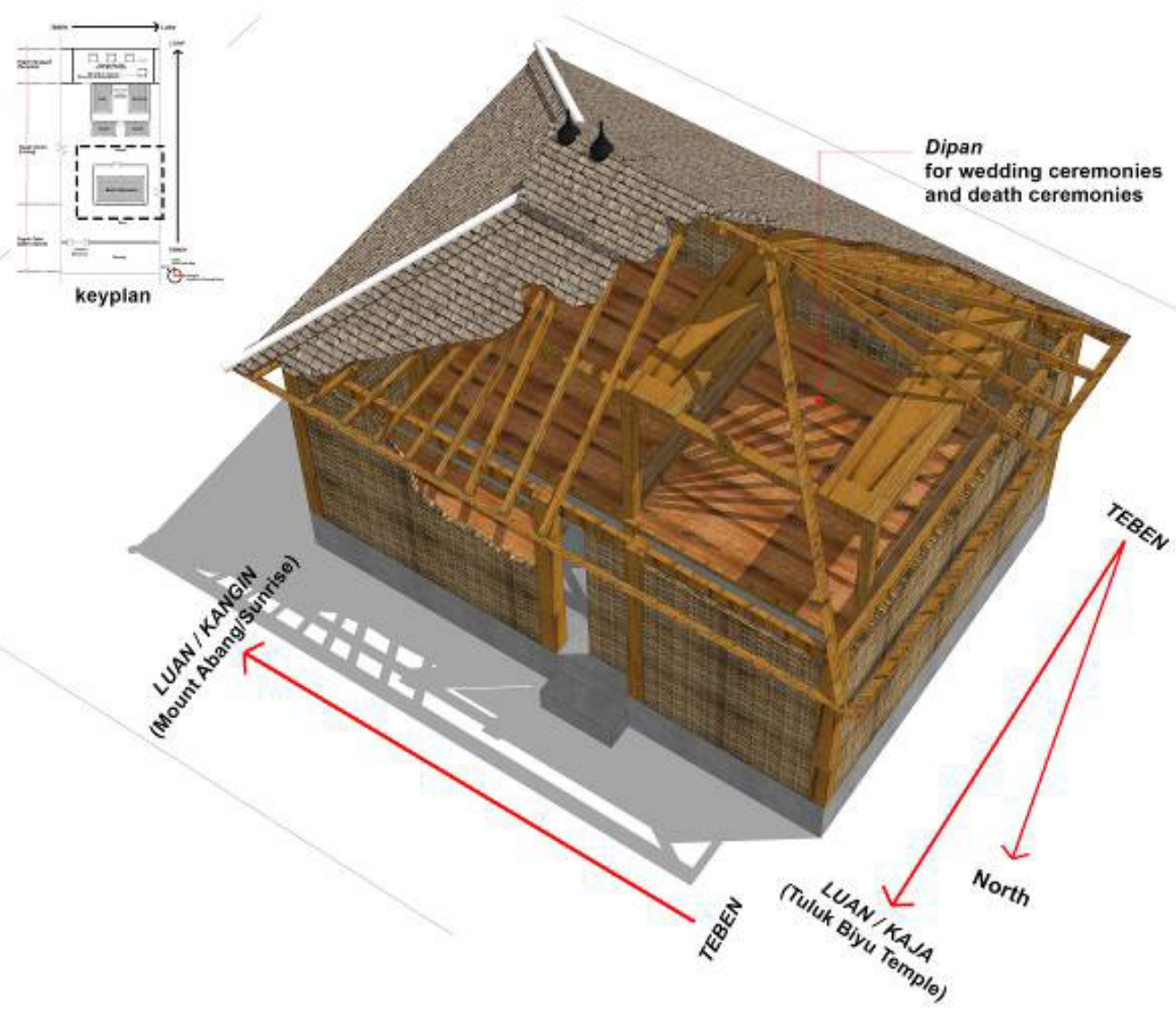

Figure 6. Luan and Teben Orientation of Bale Building 
Bale building (building for traditional activities) is in the opposite direction of the meten building (main building), forming a diametric pattern. This bale building (building for regular activities) is often referred to as Bale Adat. This Bale's orientation is towards teben (kelod / profane) with the Kaja side entrance. This Bale has 6 (six) poles, the direction of the length of the Bale in this building towards Kangin (sacred / Mount Abang) and kauh (profane). Bale buildings (buildings for traditional activities) are used for religious ritual activities, namely wedding ceremonies and death ceremonies. The orientation of the person carrying out the wedding ceremony in the direction of kangin (the direction of Mount Abang) and the head of the deceased person buried while in the room facing kangin (Mount Abang). Unlike the meten building (main building), the interior layout is oriented towards the gods' dwelling places. The traditional Bale was introduced on the slopes of Mount Abang towards Kangin (Mount Abang), which was the origin of the inhabitants of Pengotan Village. The concept of kaja (Tuluk Biyu Temple) and kangin (Mount Abang) has the same meaning, namely luan (sacred), but what distinguishes them is worship, one to God and the other to kawitan (the place of origin/ancestor) from the inhabitants of Pengotan Village. (see Figure 6).

The space between the meten building (main building) and the bale building (building for traditional activities) in the residential unit layout in Pengotan Village is called natah (plaza/middle space). In the context of luan (sacred) and teben (profane), natah (plaza/middle space) has two orientations, namely vertical and horizontal. Vertical orientation is luan (holy) as upward direction (purusa / male element) and teben (pertiwi / ground that is stepped on). The meeting between the Purusa (male aspect) and Perdana (female part) creates a cosmic balance that is carried out through the pecaruan (ceremony for spirits) tradition in the room. Natah (plaza/middle space) is also a space for liberation, namely as a space for rituals of pemelukatan (eliminating harmful elements in the human body through ways) and cleaning up dirty (dangerous) aspects of the physical body. So it can be said that natah (middle space) is a liberation room and balance point. The orientation of the bodies bathed in the natah space (middle space) is in the direction of kangin (Mount Abang) as an orientation symbol to the Pengotan Village population, where deceased humans return to their origin. (see Figure 7).

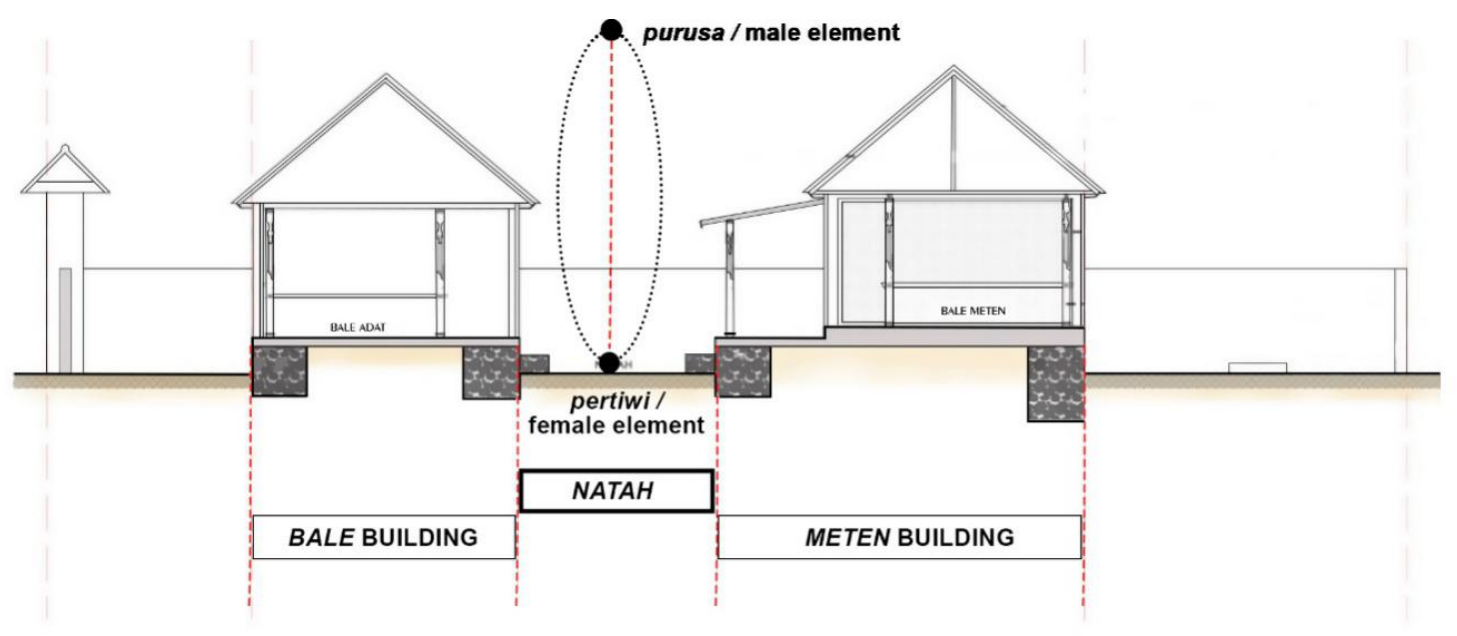

Figure 7. Natah : Space between Meten and Bale Building 


\subsection{The Influence of Luan (Sacred) and Teben (Profane) Orientation on Social and Spiritual Spatial System}

The spatial hierarchy of traditional houses is divided into three levels, tegak sanggah (sanctuary zone), tegak umah (home zone), and tegak teba (flexible space / low-value space). Tegak sanggah (sanctuary zone) consists of elements of space and the form of worship to God; tegak umah (home zone) consists of meten buildings (main building), bale buildings (building for traditional activities) and plazas (natah), and the orientation space of both times of the building. Tegak teba (flexible space / low-value space) in the form of space is usually used as a space for planting and lebuh (road). The hierarchy of the area is influenced by the conception of luan (sacred) and teben (profane) that is, the direction of luan (sacred) intended for the function of ritual activities or religious activities (tegak sanggah) and the rule of teben (profane) intended for secular parts of circulation places in and out of the yard of the house (tegak teba). Towards luan (sacred) activities are more religious and towards teben activities are profane. The spatial system of rituals occurs in the direction of luan (holy), the tegak sanggah (sanctuary zone) of the denial marked by worship activities and routines to Ancestors and God. The sacred elements of worship are pelinggih-pelinggih (adoration building) arranged in a row in the direction of luan (sacred / kaja and kangin). According to Eliade, these sacred elements as the hierophany of holy space and its position are towards religious orientation [31] [20]. The entrance to this zone is in the place or direction of teben (opposition towards luan), meaning that luan (sacred) direction is the direction intended for ritual activities marked by the position of placement pelinggih (building worship) in the order of luan while the entrance as non-ritual access is in the teben zone.

Social activities of the community in Pengotan Village in the form of wedding activities and death activities involving Pengotan Village people as a form of mutual assistance in completing these activities. Usually, the action occurs in natah (plaza) and the teba (back room of the house). Natah (middle space) as a community gathering room in carrying out social activities (secular) [13] [25]. People invited to be in or housed in plazas or natah (middle space) in wedding or death activities, lebuh (the outermost part of the house) used to prepare ritual facilities whose activities are social or help each other. Profane and secular social activities occur in the upright and tegak teba (flexible space / low-value space) with the direction of position in teben (sinful). The description above can be explained in figure 8 :

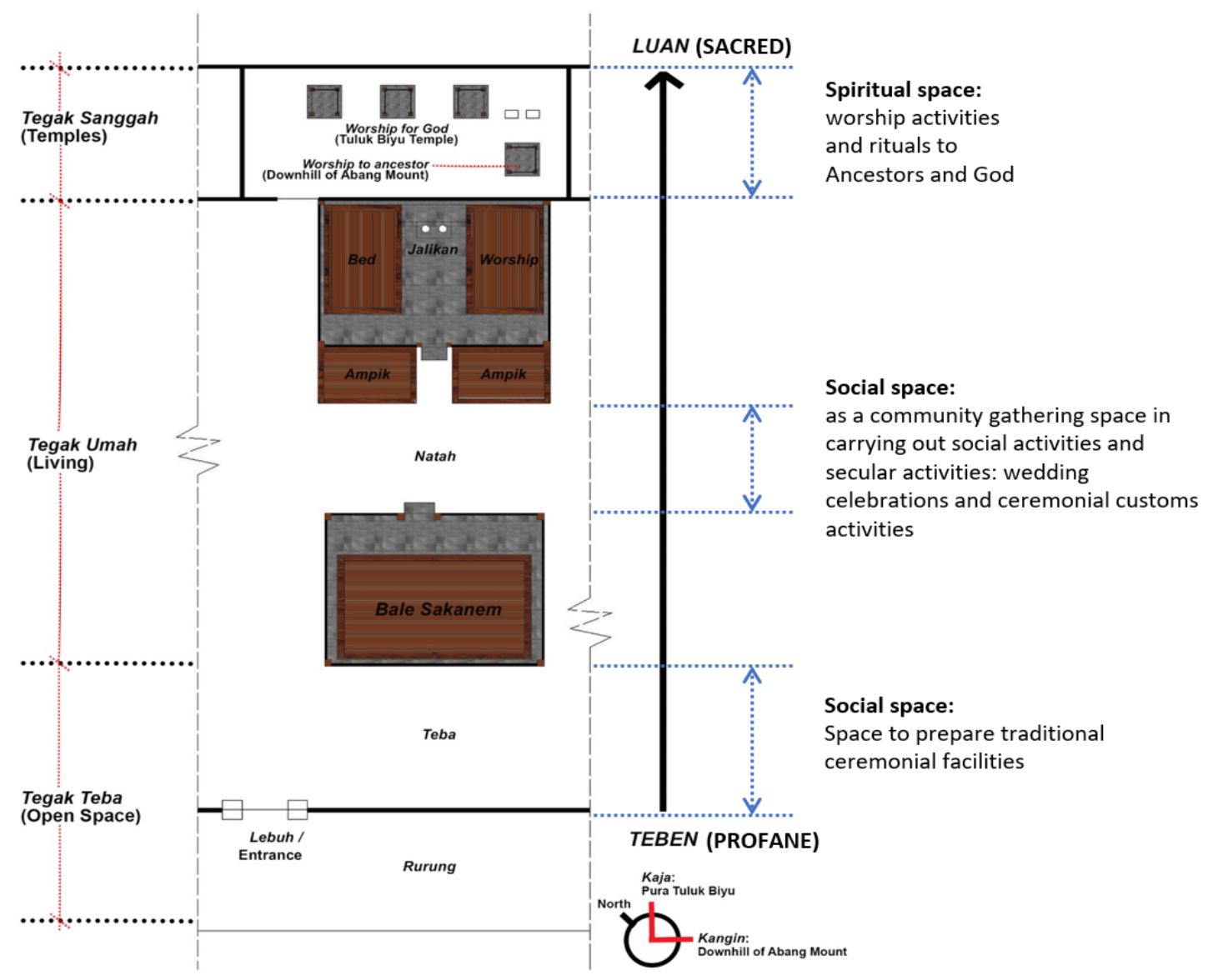

Figure 8. Spiritual and Social Spaces in House Unit 


\section{Conclusions}

The orientation of luan (sacred) and teben (profane) in the settlements of Pengotan Village is the direction of Kaja (Tuluk Biyu Temple) and Kangin (Mount Abang). Kaja (Tuluk Biyu Temple) is the axis that connects humans with their creators (God), which is marked by the Tuluk Biyu Temple as the luan (sacred) orientation. Kangin (Mount Abang) is an orientation direction that connects humans to their ancestors or Pengotan Village inhabitants' origin, namely on the slopes of Mount Abang. Kangin (Mount Abang) orientation also leads to the beginning of life marked by the direction of the sun's rising. Teben (profane) is an opposite orientation from luan (sacred), which is in the order of kelod (secular) and kauh (material). The concept of luan (holy) and teben (profane) affects the layout of macro, mezzo, and micro settlements of Pengotan Village. The spatial system of space influenced by the concept of luan (sacred) and teben (profane) affects settlements' spatial layout and involves social activities and rituals. The method of social activities occupies the direction of teben (profane and secular), namely natah (middle space) and teba (multi-function room), while the system of ritual activities is towards luan (sacred) in the zone of tegak sanggah (holy place). The means that the influence of luan (religious) and teben (profane) conception orientation is local wisdom that regulates spatial architecture and social activities and rituals in harmony with the direction of view of Pengotan Village people. The concept of this direction is different from the idea of the cosmological order in Bali. In traditional Balinese architectural cosmology, luan (sacred) direction is oriented towards the location of Mount Agung (the highest mountain in Bali). At the foot of Mount Agung, there is the largest temple adored by Hindus in Bali. When dialogue with the concept of luan (sacred) and teben (profane) in Pengotan Village, has a difference in orientation direction with the idea of the cosmological order that applies in general in Bali. Luluhur / ancestors (concept becomes the primary reference in positioning luan / sacred) movement in the spatial layout of Pengotan Village. The philosophy that can be produced in this research is the primary orientation in Pengotan village people's life system, referring to the ancestors as the origin and end of the life of the people of Pengotan Village.

\section{Acknowledgments}

The Warmadewa University Research Institute is grateful for funding Warmadewa University research and architecture students to collect data for this research activity.

\section{REFERENCES}

[1] T. A. Reuter, Custodians od The Sacred Mountains. Jakarta: Yayasan Obor Indonesia, 2005.

[2] N. K. P. A. Laksmi, "Identifikasi Tempat Suci pada Masa Bali Kuno," Linguistic.Fib.Ui.Ac.Id, pp. 208-217, 2017.

[3] A. W. Purwantiasning, "Benang Merah Terbentuknya Pola Permukiman dan Pola Hunian Desa Bali Mula Dikaitkan dengan Aspek Sosial, Ekonomi dan Budaya (Studi Kasus: Desa Pekraman Julah, Kecamatan Tejakula, Bali)," $J$. Nalars, vol. 17, no. 1, 2017.

[4] N. K. A. Dwijendra, "Meru as a Hindu Sacred Building Architecture with a High Roof and Resistant to Earthquakes in Bali, Indonesia," Civil Engineering and Architecture, vol. 8, no. 3, pp. 350-358, Jun. 2020. https://10.13189/cea.2020.080319

[5] N. K. A. Siwalatri, J. Prijotomo, and P. Setijanti, "Spatial Concepts of Bali Indigenous Architecture," Procedia - Soc. Behav. Sci., 2015.

[6] H. S. Nordholt, "Custodians of the Sacred Mountains: Culture and Society in the Highlands of Bali," J. Soc. Issues Southeast Asia, vol. 19, no. 1, pp. SJ19-1h, Apr. 2004.

[7] N. M. Yudantini, "The spatial and settlement pattern in Mabi Hamlet, Belantih Village, Kintamani: conservation of tangible and intangible of Balinese traditional architecture in Bali Aga villages," IOP Conf. Ser. Earth Environ. Sci., vol. 213, p. 012025 , Dec. 2018.

[8] I. N. W. Paramadhyaksa, N. K. A. Dwijendra, N. K. P. D. Jayanti, and I. K. M. Wijaya, "Implications Of Orientation Patterns On Spatial Planning In Pinggan Village, Bali Indonesia," Solid State Technol., vol. 63, no. 6, 2020.

[9] C. S. Alcorta and R. Sosis, "Ritual, emotion, and sacred symbols," Hum. Nat., 2005.

[10] B. R. Meagher, "Deciphering the religious orientation of a sacred space: Disparate impressions of worship settings by congregants and external observers," J. Environ. Psychol., vol. 55, pp. 70-80, Feb. 2018.

[11] L.. Sentosa, "Genius loci within Balinese dwellings environments:," Habitat Int., vol. 25, no. 2, pp. 255-272, Jun. 2001.

[12] S. H. Nasr, "Harmony of Heaven, Earth and Man-Harmony of Civilizations," Procedia - Soc. Behav. Sci., vol. 77, pp. 10-14, Apr. 2013.

[13] I. K. M. Wijaya, "Discourse On the Concept of Balance of Sakala and Niskala Spaces in Ethnic Balinese Homes," in International Seminar Bali Hinduism, Tradition and Interreligious Studies, 2018, pp. 73-80.

[14] T. Y. W. Subroto and A. S. Malangyudo, "The continuity of binary diametric space of Balinese house in Yogyakarta, Indonesia," City, Cult. Soc., vol. 5, no. 1, pp. 33-42, Mar. 2014.

[15] W. Arimbawa and I. K. G. Santhyasa, "Perspektif Ruang Sebagai Entitas Budaya Lokal Orientasi Simbolik Ruang Masyarakat Tradisional Desa Adat Penglipuran, Bangli Bali," Local Wisdom Sci. Online J., vol. 2, no. 4, 2010.

[16] N. K. A. Dwijendra, "From tradition to modernization in 
morphological process of indigenous settlement patterns in Bali, Indonesia," Int. J. Adv. Sci. Technol., vol. 29, no. 8, pp. 856-868, 2020.

[17] N. Muhadjir, Metodologi Penelitian Kualitatif Edisi IV, IV. Yogyakarta: Rake Sarasin, 2002.

[18] I. G. N. T. Adiputra, S. Sastrosamito, D. Wiyono, and A. Sarwadi, "Konsep Hulu-Teben pada Permukiman Tradisional Bali Pegunungan/Bali Aga di Desa Adat Bayung Gede Kecamatan Kintamani Kabupaten Bangli, Bali," Forum Tek, vol. 37, no. 1, pp. 14-31, 2016.

[19] I. K. M. Wijaya, "Ruang Sakala dan Niskala Di Sekitar Pohon Beringin Di Denpasar," in Seminar Nasional Space \#3: Membingkai Multikultur dalam Kearifan Lokal Melalui Perencanaan Wilayah dan Kota, 2017.

[20] B. Rennie, "Mircea Eliade: 'Secular mysticism' and the history of religions," Religion, vol. 38, no. 4, pp. 328-337, Dec. 2008.

[21] I. G. A. Paramita, "Bencana, Agama dan Kearifan Lokal," DHARMASMRTI J. Ilmua Agama dan Kebud., vol. 18, no. 1, pp. 36-44, 2018.

[22] T. N. Samadhi, "Making cosmo-religious landscapes: the design of a Balinese town's civic center (Bali, Indonesia)," Habitat Int., vol. 28, no. 1, pp. 103-122, Mar. 2004.

[23] S. Kusdiwanggo, "Membaca Dualism-Antithesis dan Dualism-Harmony sebagai Dasar Memahami Konsensus Ruang Nusantara," in Prosiding Temu Ilmiah IPLBI 2017, 2017, pp. 93-100.
[24] S. Kusdiwanggo and J. Sumardjo, "Sakuren: Konsep Spasial Sebagai Prasyarat Keselamatan Masyarakat Keselamatan Masyarakat Budaya Padi di Kasepuhan Ciptagelar," Panggung, vol. 26, no. 3, Sep. 2016.

[25] I. K. M. Wijaya, "Konsepsi Natah Dan Lebuh Sebagai 'Ruang Keseimbangan' Dalam Arsitektur Tradisional Bali," J. Arsit. Zo., vol. 2, no. 2, 2019.

[26] I. K. M. Wijaya, "Conception of Spatial Dualism around the Banyan Tree in Denpasar, Indonesia," in 3rd Annual Applied Science and Engineering Conference (AASEC 2018), 2018.

[27] I. G. M. Putra, "Perubahan Ekspresi Konsep Natah Dalam Tata Ruang Di Bali," J. Permukim. Natah Vol. 1 No. 2 Juni $200352-108,2003$.

[28] I. K. M. Wijaya, "Hubungan Arsitektur Dan Lingkungan Pada Perwujudan Rumah Tinggal Tradisional Di Desa Pengotan, Bangli," in Prosiding Seminar Nasional Teknik 2016: Tantangan Percepatan Pembangunan Infrastruktur Di Indonesia Berwawasan Lingkungan, 2016, pp. 21-32.

[29] I. W. Dana, "Paruman Tapakan Barong dalam Ritual Tapak Pertiwi,” Resital J. Seni Pertunjuk., vol. 11, no. 2, pp. 162 160, 2010.

[30] N. M. Yudantini and D. Jones, "The Catuspatha Pattern in Balinese Palace: Architectural Conservation and Challenges," Procedia Environ. Sci., vol. 28, pp. 538-548, 2015.

[31] M. Eliade, The Sacred and The Profan. New York: Harcour, Brace and Word, Inc, 1957. 